\title{
Climate sensitivity of radial growth in European beech (Fagus sylvatica L.) at different aspects in southwestern Germany
}

\author{
ERNST VAN DER MAATEN* \\ Institute for Forest Growth, Albert-Ludwigs-University Freiburg, Germany
}

\begin{abstract}
The climate sensitivity of radial growth in European beech (Fagus sylvatica L.) was analyzed within a narrow valley in the Swabian Alb (southwestern Germany). We collected stem discs from three aspects (NE, NW and $\mathrm{SW}$ ) of trees belonging to different social classes. Common climatic factors limiting growth across the valley were identified using a principal component analysis (PCA). Further, we performed hierarchical cluster analysis (HCA), redundancy analysis (RDA) and bootstrapped correlation analysis to reveal differences in chronologies and climate-growth relationships between aspect and social class.

Climatic variables considered in our analyses were monthly and seasonal data on temperature and precipitation, as well as a self-calibrating Palmer drought severity index (sc-PDSI). We identified drought in the period June August as the most prominent factor limiting growth across the valley. Dominant and co-dominant trees at the NW and SW aspect were found to be particularly drought sensitive, whereas intermediate trees were less susceptible to drought. Underlying causes of established climate-growth relationships are discussed in the context of drought susceptibility, tree-size modulation and tree physiological processes.
\end{abstract}

Original publication available at link.springer.com as: van der Maaten, E. 2012. Climate sensitivity of radial growth in European beech (Fagus sylvatica L.) at different aspects in southwestern Germany. Trees - Structure and Function, 26(3), 777-788.

\section{Introduction}

Climate change projections foresee temperature increases of $3-4{ }^{\circ} \mathrm{C}$ for Continental Europe by the end of this century. Besides, the seasonality of precipitation is expected to change with reduced rainfall in summer resulting in more frequent and severe summer droughts (Christensen et al., 2007). Thorough understanding of differences in climategrowth relationships among tree species is needed to assess the influence of climate change on future tree growth. Over recent times numerous dendro-ecological and physiological studies on the adaptation potential of tree species have been published. For European beech (Fagus sylvatica L.) drought resistance and resilience have been controversially discussed (e.g., Ammer et al., 2005; Kölling et al., 2005; Rennenberg et al., 2004). Some studies indicated that beech may lose its dominance towards more drought-tolerant tree species like oak on soils with low water availability (Geßler et al., 2007; Rennenberg et al., 2004), whereas Ammer et al. (2005) stressed a remarkably high drought tolerance of beech observed in other studies in dry areas (Dittmar \& Elling, 1999; Dittmar et al., 2003). A European-wide study pointed out that climate warming is likely to have particularly large effects on the productivity of beech in temperate climates (Ciais et al., 2005). However, dendro-ecological analyses after the 2003 drought could not substantiate these findings. Although wood formation ceased in beech during drought, growth quickly recovered after drought (Kahle, 2006; van der Werf et al., 2007).

Other studies on productivity changes of beech towards climate change reported recent growth declines from retrospective and national forest inventory data for northeastern France (Bontemps et al., 2009, 2010; Charru et al., 2010). Declines in beech vitality are as well observed in several Mediterranean areas (Jump et al., 2006; Peñuelas et al., 2007; Piovesan et al., 2008). These studies indicated that only small increases in drought stress may reduce growth of beech over large areas and may result in replacement of beech by other tree species, e.g., by Holm oak (Quercus ilex) in the Montseny mountains (Peñuelas \& Boada, 2003). Also Friedrichs et al. (2009) indicated that

*Contact author: ernst.vandermaaten@gmail.com 
minor changes in precipitation amounts could influence climatic impacts on tree growth in temperate forests in centralwest Germany. A temporal increase in correlations to drought indices was found, highlighting the importance of analyzing temporal variability in drought sensitivity as an indicator of climate change. However, a more or less stable climate-tree growth relationship observed in north-eastern Germany (Scharnweber et al., 2011) was in contrast with these findings.

For the assessment of climate change impacts and the formulation of adequate adaptive forest management strategies, climate-growth relationships should be disentangled for a variety of sites throughout the distribution area of beech. Commonly used procedures to study such relationships are based on correlations between standardized chronologies and climatic parameters (Fritts, 1976). In this study we used principal component analysis (PCA), hierarchical cluster analysis (HCA), redundancy analysis (RDA) and bootstrapped correlation analysis to provide insight into growth responses of beech towards climate variability in a narrow valley in the Swabian Alb (southwestern Germany). This low mountain range is characterized by shallow, limestone-derived soils with low water storage capacity. Our first objective was to identify driving climatic factors influencing the radial growth of European beech across the valley. Our second objective was to assess how climate-growth relationships differ in dependence of aspect [north-east (NE), north-west (NW) and south-west (SW)] and tree social class (dominant, co-dominant and intermediate). We expect to find drought as major growth-limiting factor at all aspects related to limited soil water availability in the entire valley. Higher drought-sensitivities are further expected at the NW and SW aspect due to more extreme climatic conditions here. As competition intensity may alter the climate response of trees (e.g., Piutti \& Cescatti, 1997), we expect strongest climate signals in dominant trees.

\section{Materials and methods}

\subsection{Site description}

The study area, which supports even-aged 80-100 year old beech stands, is located near Tuttlingen (altitude: 740$760 \mathrm{~m}$ a.s.l., latitude: $48^{\circ} 00^{\prime} \mathrm{N}$, longitude: $8^{\circ} 50^{\prime} \mathrm{E}$ ) within the low mountain range Swabian Alb (southwestern Germany). Experimental sites are situated at north-east, north-west and south-west exposed slopes of a narrow valley, and are not more than $750 \mathrm{~m}$ apart. Over the Climate Normal Period 1961-1990, mean annual air temperature is about $7.0^{\circ} \mathrm{C}$ and annual precipitation sums up to $900 \mathrm{~mm}$. Seasonal courses of temperature and precipitation are depicted in Fig. 2.1. Meteorological data were provided by the German Weather Service (DWD), and are more extensively described under "Climate data" (Section 2.3). Soils are characterized as Terra Fusca-Rendzinas from limestone and are shallow $(<20 \mathrm{~cm})$, before becoming dominated by bedrock. The soil profile on the SW aspect is especially rocky containing over 40 vol\% rocks and stones in the top-layer of the soil (Hildebrand et al., 1998). Combined with higher radiation interception and evaporation rates (Mayer et al., 2002) water availability is lower here. Slopes are steep and have an inclination of $23-30^{\circ}$. Study sites are highly representative for beech forests in the Swabian Alb.

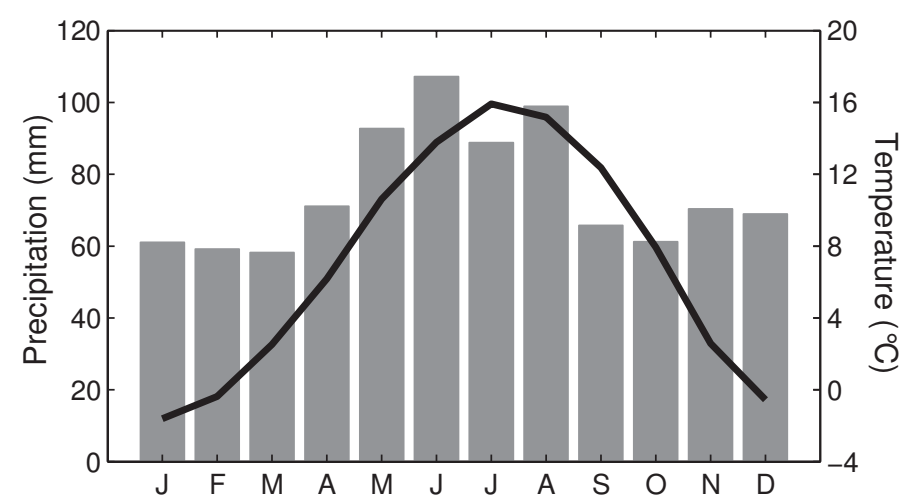

Figure 2.1: Climate diagram of mean monthly precipitation sums $(\mathrm{mm})$ and air temperatures $\left({ }^{\circ} \mathrm{C}\right)$ over the Climate Normal Period 1961-1990

Mean stand height, diameter at breast height $(\mathrm{DBH})$ and basal area are higher at the northern compared to the southern aspect. A forest inventory in 2001 reports a mean height of $26.5 \mathrm{~m}$, a mean DBH of $25.6 \mathrm{~cm}$ and a basal area of $27.0 \mathrm{~m}^{2} / \mathrm{ha}$ for the northern, compared to $21.1 \mathrm{~m}, 21.5 \mathrm{~cm}$ and $21.0 \mathrm{~m}^{2} /$ ha for the southern aspect under a comparable stocking density of about 530 trees per hectare (Hauser, 2003; Holst et al., 2005). 


\subsection{Tree-ring data}

In the winter of 2009-2010 stem discs were collected at DBH from beech trees growing at the NE, NW and SW aspect. At each aspect 9 trees were sampled equally distributed among the tree social classes 1, 2 and 3 after Kraft (1884). The third social class forms the lower limit of the dominant trees. Hereinafter, the Kraft classes are referred to as dominant, co-dominant and intermediate. In addition, stem discs collected in the winter of 1998-1999 (Spiecker et al., 2001) following the same sampling strategy were included in the dataset $\left(n_{\text {total }}=6\right.$ trees $\times 3$ social classes $\times$ 3 aspects $=54$ trees).

Stem discs were air-dried and sanded. Radial growth was measured in eight pre-defined directions using semiautomatic image analysis software, and visually and statistically cross-dated with a reference chronology. Individual tree growth series were computed as quadratic means of the eight radii. Detrending and standardization was performed using MATLAB ${ }^{\circledR}$ 's (R2009b, the MathWorks, Inc.) Spline toolbox function csaps (V3.3.7) in combination with the spline smoothing parameter function splinep (presented courtesy of J.L. Dupouey). A cubic-smoothing spline with a $50 \%$ frequency cut-off of 30 years was applied in order to preserve the high-frequency variability (Cook, 1985; Cook \& Peters, 1981).

Stand chronologies were constructed per social class and aspect, and inter-series correlations (IC), mean sensitivities (MS) and first-order autocorrelations (AC) were calculated over the common overlap period 1934-1998. IC is a measure of the strength of the common signal in a chronology revealing the similarity in tree growth to inter-annual climatic variability, MS is a within-series statistic that measures the relative change in radial growth from one year to the next, and AC is a measure of the previous year's influence on current year's growth (Fritts, 1976). Furthermore, the expressed population signal (EPS) was calculated using the wigleyl function (D. Meko). This statistic measures how well a chronology drawn from a finite number of trees approximates the theoretical population chronology based on an infinite number of trees (Wigley et al., 1984). All statistical parameters were calculated in MATLAB ${ }^{\circledR}$ (R2009b, the MathWorks, Inc.).

\subsection{Climate data}

The German weather service provided climate data on monthly mean air temperature and precipitation sums. Sitespecific data was extracted for the period 1900-2009 from a gridded climate surface with a high spatial resolution of $1 \times 1 \mathrm{~km}$. This gridded dataset is available for registered users from the web-based weather request and distribution system (WebWerdis, 2011). Gridded climate data was carefully checked with on-plot meteorological tower measurements at the NE and SW aspect over the period 2001-2007 (Meteorological Institute, Albert-Ludwigs-University Freiburg). Although differences in daily temperature courses exist between these aspects, e.g., with higher maximum temperatures at SW, monthly temperature courses are highly comparable. A high similitude and correlation with the gridded data $(r=0.996, P<0.001)$ nullified the need for a correction of the gridded data according to the actual climate data. Rainfall does not vary significantly across the valley (Geßler et al., 2001), and was highly correlated with the gridded climate data as well $(r=0.955, P<0.001)$.

A self-calibrating Palmer drought severity index (sc-PDSI) was then calculated using a downloadable tool from the Greenleaf Project (GreenLeaf-website, 2011). Besides temperature and precipitation, latitude and available water capacity (AWC) are required as input variables. In the calculation of sc-PDSI series we used AWC levels of $110 \mathrm{~mm}$ for the northern aspects (NE and NW) and $90 \mathrm{~mm}$ for the more shallow and water-limited SW aspect (Hildebrand et al., 1998; Matzarakis et al., 2000), respectively.

The sc-PDSI (Wells et al., 2004) is a variant of the original drought index by Palmer (1965) (PDSI). It improves upon the PDSI by automatically calibrating climatic characteristic and duration factors based on historic temperatures, precipitation sums and AWC levels at the given locations, making spatial comparisons more meaningful (van der Schrier et al., 2006; Wells et al., 2004). Values normally range between -4 (extreme drought) and +4 (extremely wet), while values near zero indicate normal soil moisture conditions (Palmer, 1965).

\subsection{Statistical analyses}

We performed a PCA to reveal common patterns of growth variation in stand chronologies for the overlap period 1934-1998. This common signal is captured by the first principal component (PC1). We plotted the PC1 scores and analyzed climate in years with remarkable growth depressions (selection criteria used: PC1 score $<-0.5$ ) to understand radial growth responses in these distinct years across the valley.

Hierarchical cluster analysis (HCA) was applied to group stands based on similarity (or dissimilarity) of the chronologies in such a way that stands in the same cluster are most similar, whereas stands in different clusters are quite distinct. Euclidian distances between the nine chronologies were calculated and stands were grouped according 
to Ward's minimum variance method. At each step of the hierarchical process stands were joined using an analysis of variance approach, while minimizing the error sum of squares (ESS) (Ward, 1963). Results of the HCA are presented as a dendrogram.

We calculated bootstrapped correlation coefficients on individual stand chronologies and climate data to identify climatic factors responsible for the observed growth variation. Monthly climate data on mean air temperature, precipitation sums and mean sc-PDSI values were included in the correlation analysis over a 17 month window from April of the previous year to current August. Additionally, seasonal climatic variables were included for the periods March - May, June - August and March - August, hereinafter referred to as periods I, II and III. Bootstrapped correlation coefficients were calculated for the period 1934-1998 using the software package DENDROCLIM 2002 (Biondi \& Waikul, 2004). In addition, we performed a redundancy analysis (RDA) to conveniently visualize differences in climatic responses between aspect and social class. RDA is a multivariate direct gradient analysis method that can be considered an extension of PCA and multiple regression, and was successfully applied to dendrochronological data in various studies (e.g., Friedrichs et al., 2009; Tardif et al., 2003). The technique is intended to display main trends in variation of a multi-dimensional dataset in a reduced space of selected, linearly independent dimensions (Legendre \& Legendre, 1998). In RDA ordination diagrams, the ordination axes are constrained to be linear combinations of supplied environmental variables (Lepš \& Šmilauer, 2003; ter Braak, 1994). Our RDA was performed on stand chronologies and monthly climate data over the indicated 17 month window and common overlap period using the program CANOCO (version 4.5, ter Braak \& Šmilauer, 2002). Years were considered as samples (sites) and stand chronologies for the different tree social classes as descriptor (species) (mode $Q$ according to Legendre \& Legendre, 1998). Significant climatic variables $(P<0.05)$ were obtained using a Monte Carlo forward selection based on 999 random samplings.

We did not include climate data for current year September in our RDA and bootstrapped correlation analysis as it is known from long-term local dendrometer monitoring that radial growth usually stops in August. However, when studying tree ring parameters other than radial increment, i.e., wood density, climatic conditions in this month may have an influence. Allocation of assimilates towards secondary cell wall building is reported to continue for several weeks in beech after cell division and enlargement has stopped (Bouriaud et al., 2004; Lachaud \& Bonnemain, 1981).

\section{Results}

\subsection{Chronology characteristics}

Measurement of annual radial growth revealed differences in the mean tree age among the experimental sites. In 1998, trees at the $\mathrm{NE}$ aspect had a mean age of $\sim 70$ years $(\mathrm{SD}=4.3)$ at $\mathrm{DBH}$, whereas trees at the $\mathrm{NW}$ and $\mathrm{SW}$ aspects were somewhat older with mean ages of $92(\mathrm{SD}=2.1)$ and $82(\mathrm{SD}=4.3)$ years, respectively. Mean radial increment, based on eight radii per tree, was generally highest at NE (Table 1).

Table 1: Characteristics of study trees

\begin{tabular}{|c|c|c|c|c|c|c|c|c|c|c|}
\hline \multirow[t]{2}{*}{ Social class } & \multirow[t]{2}{*}{ Aspect } & \multirow[t]{2}{*}{$N$} & \multicolumn{4}{|l|}{ Raw data } & \multicolumn{4}{|c|}{ Standardized chronologies } \\
\hline & & & Age (years) & $\mathrm{DBH}(\mathrm{cm})$ & Height (m) & $\mathrm{RI}(\mathrm{mm})$ & IC & MS & $\mathrm{AC}$ & EPS \\
\hline \multirow[t]{3}{*}{ Dominant } & $\mathrm{NE}$ & 6 & $71.7(4.7)$ & $35.5(2.2)$ & $27.6(2.3)$ & $2.21(0.49)$ & 0.774 & 0.193 & 0.073 & 0.954 \\
\hline & NW & 6 & $92.5(1.6)$ & $37.1(1.3)$ & $32.4(1.3)$ & $2.13(0.58)$ & 0.814 & 0.200 & 0.180 & 0.963 \\
\hline & SW & 6 & $85.3(3.6)$ & $30.8(1.0)$ & $22.8(1.2)$ & $1.80(0.56)$ & 0.805 & 0.203 & 0.237 & 0.961 \\
\hline \multirow[t]{3}{*}{ Co-dominant } & $\mathrm{NE}$ & 6 & $69.7(4.8)$ & $27.3(1.0)$ & $25.9(3.5)$ & $1.78(0.49)$ & 0.713 & 0.196 & 0.221 & 0.937 \\
\hline & NW & 6 & $91.7(2.3)$ & $28.3(0.9)$ & $29.0(0.3)$ & $1.48(0.41)$ & 0.839 & 0.209 & 0.254 & 0.969 \\
\hline & SW & 6 & $82.2(4.8)$ & $24.8(0.7)$ & $22.6(2.5)$ & $1.47(0.57)$ & 0.838 & 0.203 & 0.278 & 0.969 \\
\hline \multirow[t]{3}{*}{ Intermediate } & $\mathrm{NE}$ & 6 & $70.2(3.9)$ & $22.1(1.7)$ & $24.8(1.7)$ & $1.40(0.53)$ & 0.671 & 0.214 & 0.332 & 0.924 \\
\hline & NW & 6 & $91.3(2.5)$ & $21.6(2.9)$ & $26.0(2.8)$ & $1.01(0.37)$ & 0.755 & 0.219 & 0.373 & 0.949 \\
\hline & SW & 6 & $79.3(2.3)$ & $18.1(1.2)$ & $20.3(0.9)$ & $1.19(0.46)$ & 0.810 & 0.211 & 0.252 & 0.962 \\
\hline
\end{tabular}

Average values are presented for age age at breast height, $D B H$ diameter breast height, height tree height, $R I$ radial increment. Values in parentheses denote standard deviations. Radial increment and standardized chronology statistics are presented for the common overlap period 1934 - 1998. $N$ number of trees, $I C$ inter-series correlation, $M S$ mean sensitivity, $A C$ first-order autocorrelation, EPS expressed population signal

Expressed population signal values range between 0.924 and 0.969 (Table 1) and are well above the generally applied threshold of 0.85 (Wigley et al., 1984), and thus indicate that the theoretical population for each chronology is well represented. A high reliability of the chronologies is further indicated by high inter-series correlation coefficients that range between 0.671 and 0.839 . Mean sensitivity ranges between 0.193 and 0.219 , and tends to be lowest at 
NE indicating that beech is more complacent here. The first-order AC varies between 0.073 and 0.373 . The effect of previous year carbohydrate storage is characteristic for deciduous trees as considerable root, shoot and cambial growth occurs before leaves have fully expanded and reached their full photosynthetic capacity (Kozlowski \& Pallardy, 1997). Autocorrelation values indicate that this effect tends to be strongest in intermediate trees.

\subsection{Common growth patterns}

The PC1 of our PCA captures the major common growth signal across the valley and explains $78 \%$ of the total variance in our stand chronologies. Scores of the PC1 are plotted (Fig. 3.1) to identify years of growth depression. Using an arbitrarily set selection criterion of PC1 score $<-0.5$, these years are: 1935, 1941, 1945, 1948, 1949, 1957, 1962, 1964, 1976 and 1981. Meteorological diagrams for these years are depicted in Fig. 3.2.

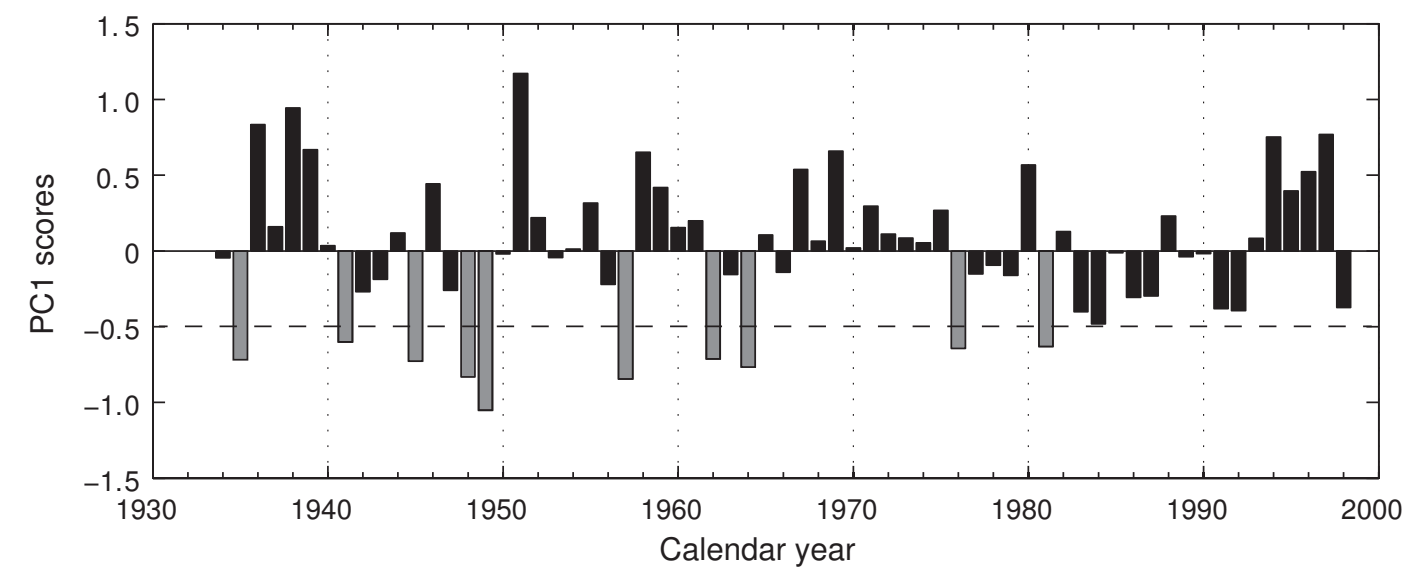

Figure 3.1: PC1 scores describing the common signal of stand chronologies over the overlap period 1934-1998. Gray bars indicate years with remarkable growth depressions
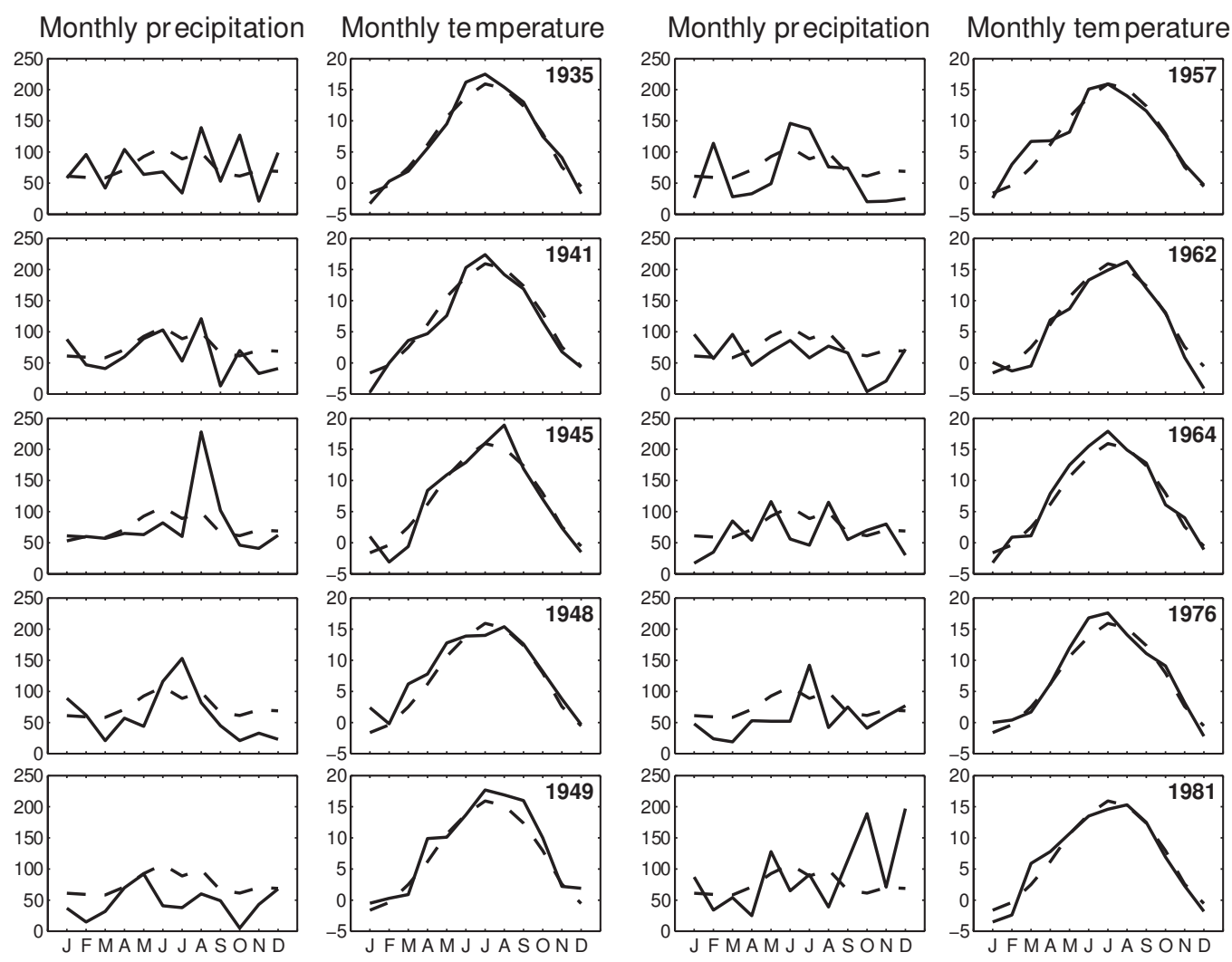

Figure 3.2: Meteorological diagrams of monthly precipitation $\left(\mathrm{mm}\right.$, left) and mean air temperature $\left({ }^{\circ} \mathrm{C}\right.$, right) for selected years (Fig. 3.1). Dotted lines indicate average climatic conditions over the period 1961-1990 
The strongest growth depression was found in 1949. With an annual and growing season (March - August) precipitation sum of only 550 and $333 \mathrm{~mm}$, respectively, 1949 is the driest year in the study area over the period 1900-2009. Besides, precipitation amounts were already low since September 1948. Below-average precipitation levels are also observed in 1935 (from May till July), 1945 (April - July), 1948 (March - May), 1957 (March May), 1962 (April - August), 1964 (June - July) and 1976 (January - June), and might explain the observed growth reductions. Warm periods during these years may have intensified water stress (e.g., above-average temperatures from April - July in 1964). Moreover, lagged effects of previous year climatic conditions are likely for some years as well. Extreme high temperatures and low precipitation amounts in 1947 might, for example, have negatively affected growth in 1948. Similarly, dry conditions throughout 1934 may have negatively impacted growth in 1935, and dry periods during 1971-1975 may have reduced beech vitality, exaggerating the growth depression in 1976. Further, a lagged effect of previous year conditions is likely for 1957, as extreme cold February temperatures of $-10.4^{\circ} \mathrm{C}$ (on average) already negatively affected tree growth in 1956.

Frost damage linked to cold temperatures in January 1941 might explain the growth reduction observed in this year. The causes of the growth depression observed in 1981 cannot be clearly explained, although a dry-warm period in early spring as well as little precipitation in June and August may be postulated as possible causes.

Climatic conditions in years with positive growth responses were not fully analyzed as strong positive growth reactions are often caused by a combination of several favorable factors, rather than a single extreme climatic anomaly (Rolland et al., 2000). However, climate in years of growth recovery is generally characterized by very moderate water stress. Especially in 1951 growth recovery is evident after a period of depression (1947-1949; Fig. 3.1).

\subsection{Growth variations}

Hierarchical cluster analysis (HCA) of the stand chronologies produced a dendrogram (Fig. 3.3). Three main clusters were identified. The first cluster is made of beech stands growing at the SW aspect, whereas the second and third cluster consist of stand chronologies for the NW and NE aspects, respectively. The dendrogram clearly shows an initial split between the SW/NW and NE. Further, co-/dominant stand chronologies are separated from intermediate chronologies in each cluster, indicating a high similarity in growth of the dominant and co-dominant trees.

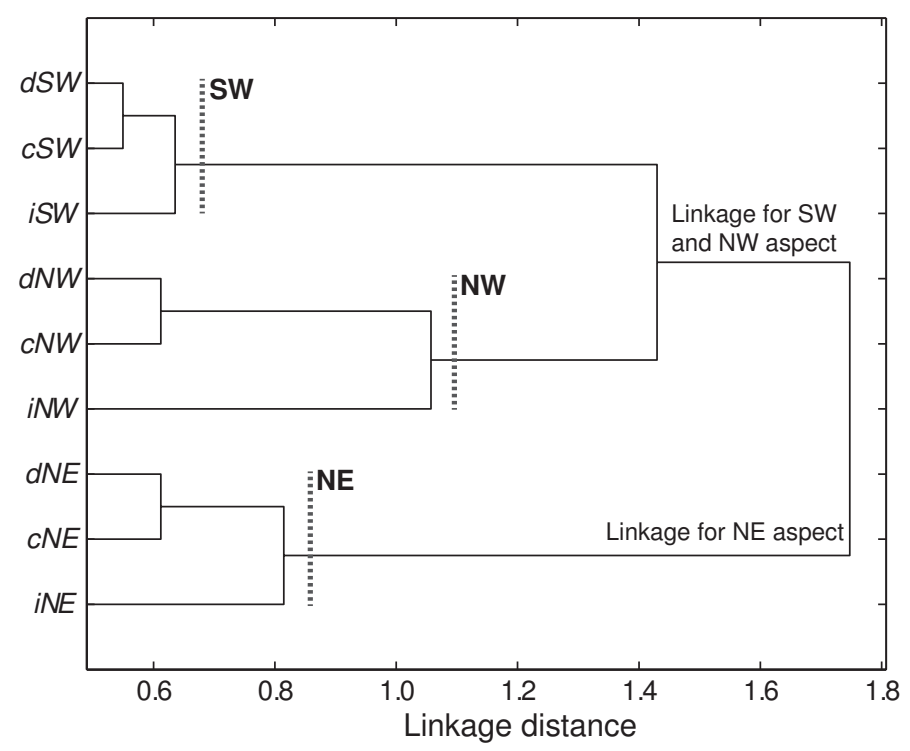

Figure 3.3: Dendrogram presenting the results of the hierarchical cluster analysis performed on nine stand chronologies (Table 1). Tree social class of the chronologies is indicated by a prefix ( $d$ dominant, $c$ co-dominant, $i$ intermediate)

\subsection{Climate-growth relationships}

We performed redundancy analysis to visualize major climate responses of our chronologies. As AWC levels and associated sc-PDSI series differ between the northern and southern aspect, separate RDA bi-plots were constructed for the NE and NW aspect (Fig. 3.4a) and for the SW aspect (Fig. 3.4b). Fig. 3.4a allows a social class and aspect comparison for the northern aspects, whereas Fig. 5b facilitates a social class comparison at SW. In the bi-plots, stand chronologies are depicted as symbols and significant climatic variables $(P<0.05)$ as vectors. Symbols can be projected perpendicularly onto a line overlaying a vector to approximate the optima of a stand chronology with respect 
to the values of the climatic variable. For the northern aspect, ten significant climatic variables were obtained after a Monte Carlo forward-based selection. These variables explain about $64 \%(0.561$ of 0.875$)$ of the total variability in the radial growth dataset explained by all climatic variables used in the RDA. For the SW aspect, six climatic variables explain approximately $55 \%$ ( 0.454 of 0.832$)$ of the variability in growth.

Long vectors for precipitation in June (Fig. 3.4a) and August (Fig. 3.4b), and for sc-PDSI in July (Fig. 3.4b) and August (Fig. 3.4a,b) indicate water shortage from June to August as major growth-limiting factor in the valley. North-east and north-west chronologies are clearly grouped (Fig. 3.4a). Positive correlations with sc-PDSI in July and August (vectors PDSI7 and PDSI8) are stronger at NW. Weakest positive correlations are indicated for intermediate trees at both aspects. Positive correlations with previous year October temperature (pT10) are inversely related with social class at NE, whereas very weak or absent at NW. The same holds for temperatures in May (T5). Negative correlations with previous year September temperature (pT9) are especially pronounced at NW. Current January temperature (T1) positively influences growth, which effect is stronger at NE.

PDSI8, T1 and pT9 are the most important climatic variables to explain radial growth at the SW aspect (Fig. 3.4b). Positive correlations with sc-PDSI in August (PDSI8) and negative correlations with previous year September temperatures (pT9) are strongest for co-dominant, followed by dominant and intermediate trees. High January temperatures (T1) are indicated to positively influence growth of all chronologies. Positive correlations with previous and current year August precipitation (pP8 and P8) do not differ with social class.

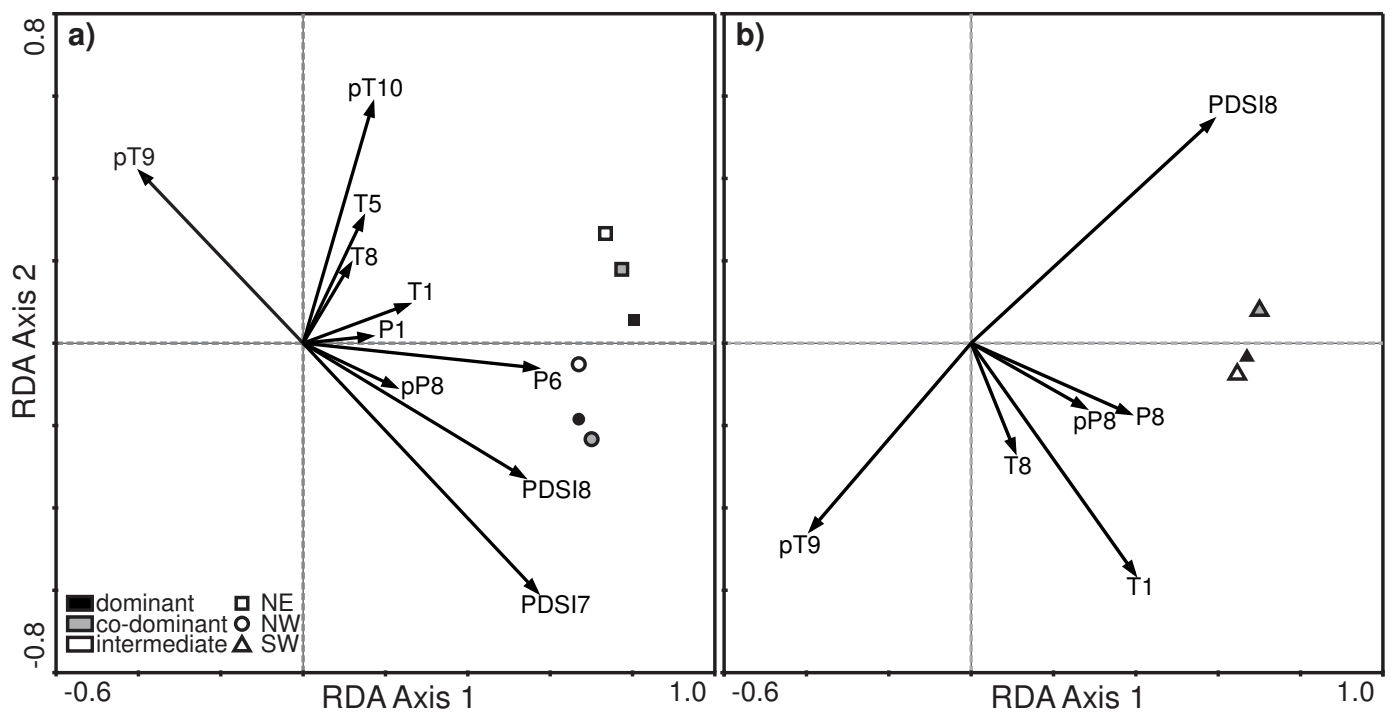

Figure 3.4: Ordination diagrams for the $\mathbf{a}$ NE- and NW-, and $\mathbf{b}$ SW-chronologies. RDAs were calculated from individual stand chronologies and monthly climate variables over the period 1934-1998. Temperature $(T)$, precipitation $(P)$ and a self-calibrating Palmer drought severity index $(P D S I)$ were included in the analysis over a 17 month window from April previous year to August current year. Vectors indicate significant climatic variables $(P<0.05)$ that were obtained using a Monte Carlo forward based selection. The length of a vector indicates its strength. Number suffixes represent months ( 1 January -12 December) and $p$ indicates previous year climate variables. Symbols and colors are used to identify particular chronologies (see legend)

To specify the level of monthly and seasonal correlations in relation to aspect and social class, we calculated bootstrapped correlation coefficients between monthly (17 month window) and seasonal (periods I, II and III) climate data and individual stand chronologies (Fig. 3.5). Significant positive correlations $(P<0.05)$ with precipitation in June, July and August as well as in the periods II and III are generally found at all three aspects (Fig. 3.5b). Although temperature trends are less clear in these months and periods (Fig. 3.5a), negative tendencies in combination with the positive correlations with precipitation identify drought in the period June - August as the major growth-limiting factor across the valley, being in accordance with the RDA. This is also supported by the integrative climate parameter sc-PDSI, which indicates significant positive correlations from June to August and for the periods II and III (Fig. 3.5c). Generally higher correlations for dominant and co-dominant stand chronologies indicate a more pronounced climate sensitivity of these trees.

Negative correlations with previous year September temperature are found across the valley as well, whereas positive correlations with previous year October temperature are only found at the NE aspect. An indicated positive effect of current January temperature is only significant for the SW chronologies. 
N
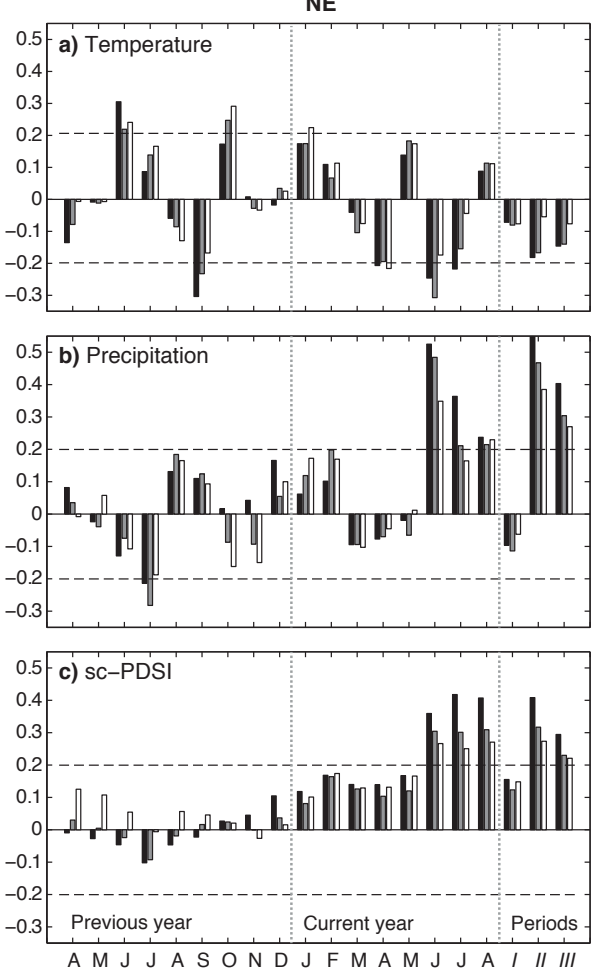

NW
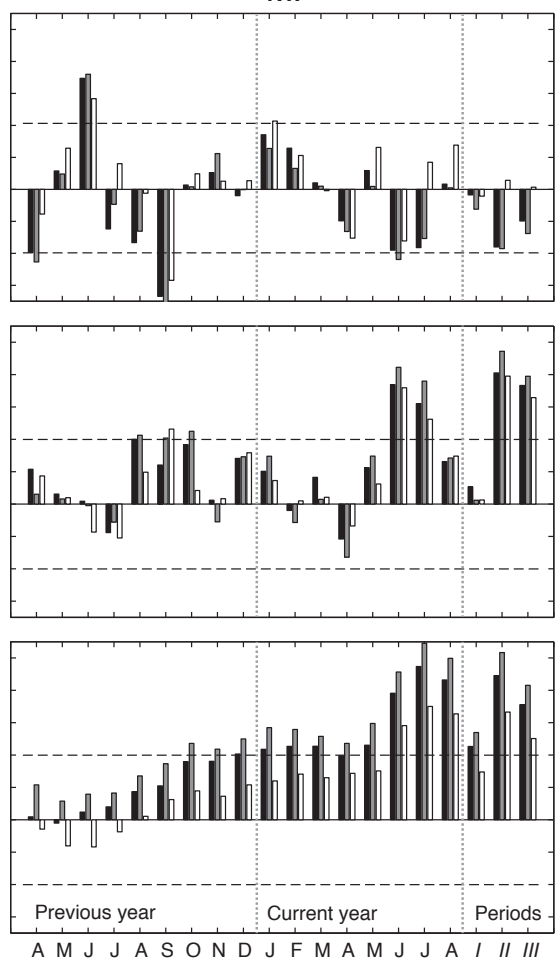

SW
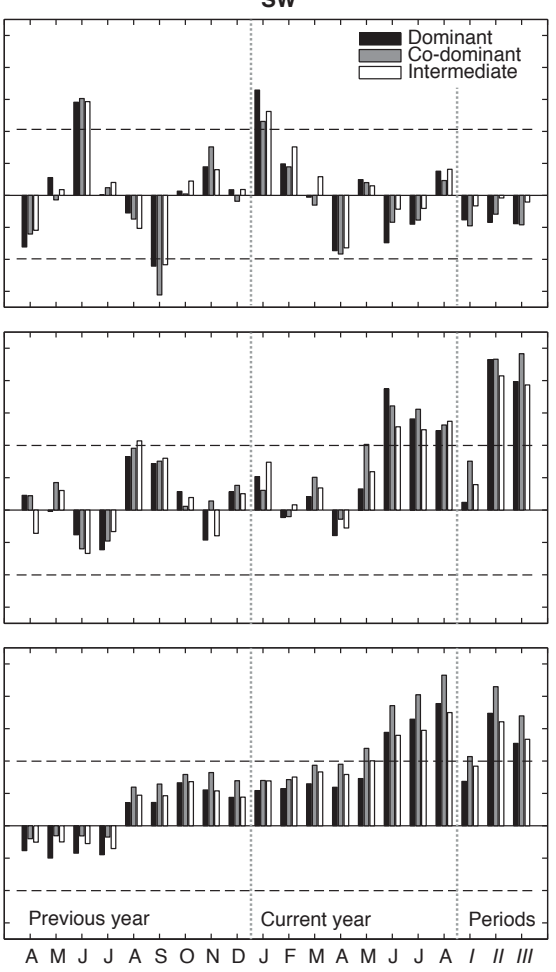

Figure 3.5: Bar diagrams of bootstrapped correlation coefficients between stand chronologies and monthly (April previous year to August current year) and seasonal climatic variables. Results on a mean temperature, b precipitation sums and $\mathbf{c}$ average sc-PDSI-levels are presented for the NE (left), NW (middle) and SW (right) plot. The significance level of the correlations $(P<0.05)$ is indicated by dotted lines. Seasonal climatic variables are calculated for the periods I March - May, II June - August and III March - August

\section{Discussion and conclusion}

Our results show a high suitability of tree-ring analyses to resolve climatic impacts on the growth of European beech (F. sylvatica L.), which is in agreement with previous studies on this species (e.g., Dittmar et al., 2003; Lebourgeois et al., 2005; Scharnweber et al., 2011). Statistical variables (Table 1) indicate a high quality of stand chronologies obtained. High IC values suggest a common climatic forcing of tree growth within dominance classes at all aspects. Besides, high EPS values for all chronologies underline a strong climatic signal. Chronology statistics well reflect differences between aspect and social class. Generally decreasing mean RI and increasing IC and MS values from $\mathrm{NE}$ to NW and SW indicate that beech is more complacent at the climatically less extreme NE aspect. This finding is in accordance with theoretical variations of dendrochronological characteristics along increasing drought intensity as proposed by Fritts (1976). Adaptations in tree architecture are indicated by lower stand height and basal area at the more drought-prone SW aspect.

\subsection{Growth depressions}

A PCA revealed the common growth pattern across the valley (PC1 scores, Fig. 3.1). PC1 explained 78\% of the total variation in our stand chronologies and captured the major climatic signal. Analyzing climate in years with remarkable growth depressions (Fig. 3.2) revealed drought, frost damage and lagged effects of the latter two as important causes of growth decline. Climate in years of growth recovery was generally characterized by very moderate water stress.

To provide deeper insight in climate-growth relationships in extreme years, other studies frequently used so-called pointer year analyses (e.g., Dittmar \& Elling, 1999; Lebourgeois et al., 2005; Neuwirth et al., 2007). Pointer years identify growth reactions caused by abrupt changes in environmental conditions, e.g., climate (Schweingruber, 1996), and may be defined over Cropper-values (Neuwirth et al., 2007) or expressed as a relative growth change in percent (Becker et al., 1994; Lebourgeois et al., 2005). The years of growth depression identified by our PCA (1935, 1941, 1945, 1948, 1949, 1957, 1962, 1964, 1976 and 1981) are in accordance with documented pointer years. Numerous years are in common with studies in different areas and within different tree species (Becker et al., 1989, 1994; Grundmann et al., 2008; Lebourgeois, 2007; Lebourgeois et al., 2005; Neuwirth et al., 2007), highlighting that during years of extreme climatic conditions Central European trees show uniform reactions, whereas regional differences in 
growth reactions occur in years of less pronounced and widespread weather conditions (Neuwirth et al., 2007).

Although the majority of negative growth reactions in beech could be explained by dry conditions, masting years can be considered as an additional cause of observed growth depressions. A negative correlation between fruit production and radial growth is often found for beech (e.g., Dittmar et al., 2003; Drobyshev et al., 2010), which does not necessarily reflect resource limitation or trade-off between reproductive and vegetative growth rather than different responses of fructification and stem growth to internal and external conditions (Mund et al., 2010). As no information on fructification is available for our study site over the period 1934-1998, no years of remarkable growth depressions could be definitely related to masting. However, in a literature study on beech masting in Germany (Paar et al., 2011) the years 1948 and 1976 are in common with our years of growth reduction. Both years are preceded by dry years, which are reported as important trigger for the occurrence of masting in beech (Drobyshev et al., 2010; Piovesan \& Adams, 2001). Additional growth-reducing effects of masting are especially likely in the dry year 1976, whereas this effect is questionable in 1948 considering the young mean age of trees, especially at NE.

\subsection{Climate limitations on tree growth}

Our HCA indicated clear differences in growth patterns between aspect, and initially splitted the more drought-prone NW and SW aspects from NE (Fig. 3.3). A following separation of co-/dominant from intermediate chronologies indicates a high similarity in growth of trees belonging to the highest social classes. Suggested differences in growth responses with tree size and competition intensity are reported in various studies (Cescatti \& Piutti, 1998; Cherubini et al., 1998; Gómez-Aparicio et al., 2011). For France, Mérian \& Lebourgeois (2011) found significant differences in climate sensitivity of beech, with larger trees being more sensitive to summer droughts than smaller trees. Generally stronger correlations for co-/dominant trees found in our bootstrapped correlation analysis (Fig. 3.5) are in agreement with this finding. However, these differences are not omnipresent, which might relate to different sampling strategies in both studies. In our study we selected only dominating trees belonging to the Kraft classes 1, 2 and 3, whereas Mérian and Lebourgeois sampled the biggest and smallest trees in a stand (cf. Cherubini et al., 1998). Studies on size-mediated differences in climate-growth relationships highlight the importance of assessing growth among all diameter classes, rather than sampling only the largest diameter trees. Only this would allow unbiased predictions on the consequences of climate change and the formulation of adequate adaptive forest management measures for forest ecosystems (de Luis et al., 2009).

The main climatic signal in common between aspect and social class in this study was drought from June to August, as indicated by numerous significant negative temperature correlations and positive correlations with precipitation and sc-PDSI in June, July, August as well as the periods II and III (Fig. 3.5). Long vectors for P6, P8, PDSI7 and PDSI8 in our RDA support this finding (Fig. 3.4). The observation from local dendrometer monitoring that radial growth usually starts in May and ceases at the end of August, with the major part of the tree ring formed in June and July (cf. Bouriaud et al., 2004; Schmitt et al., 2000), illustrates the importance of water-availability for tree growth in these months. On our study sites with shallow soils and low AWC levels water limitation may occur quickly, inhibiting photosynthesis, transpiration and cell development due to rapid stomatal closure (Aranda et al., 2000; Epron \& Dreyer, 1990; Raftoyannis \& Radoglou, 2002). Established climate-growth relationships are generally in agreement with those found in other parts of Germany (Dittmar \& Elling, 1999; Friedrichs et al., 2009; Scharnweber et al., 2011), in different low-elevation beech forests in Central Europe (Dittmar et al., 2003), in France (Lebourgeois et al., 2005), southern Sweden (Drobyshev et al., 2010), Ireland (García-Suárez et al., 2009) and the Netherlands (van der Werf et al., 2007). However, the importance of previous summer water availability for wide tree rings in the following year is not clearly detectable in our correlations as positive correlations with previous year precipitation in August and September are largely non-significant. These positive associations in combination with negative temperature tendencies in August and September, being highly significant for the latter month, highlight the importance of water availability for carbohydrate storage (Kozlowski \& Pallardy, 1997). The negative association with previous year September temperature may be explained by depletion of structural carbohydrate reserves under high evaporative demand in late summer, limiting carbohydrate availability for radial growth in the next year. The dependence of current year growth on carbohydrate reserves is documented in various studies on beech (Drobyshev et al., 2010; Lebourgeois et al., 2005; Saurer et al., 1997; Skomarkova et al., 2006).

The positive correlation with previous year October temperature at NE could result from a prolongation of the physiologically active period at the end of the growing season. Translocation of sugars and nutrients from the leaves to perennial parts of the tree is reported to peak in October for sessile and red oak (Quercus petraea Mill. and Q. rubra L.) (Barbaroux \& Bréda, 2002), and similar mechanisms might increase the availability of energy reserves for growth of beech during the next year (Drobyshev et al., 2010). 
Associations with previous year September and October temperatures seem to be mediated by tree size. Trees belonging to higher dominance classes have larger crowns and will therefore face higher evaporative water losses (Střelcová et al., 2002) under high September temperatures depleting more carbohydrate reserves. This hypothesis is supported by a higher drought sensitivity observed in larger beech trees in France (Mérian \& Lebourgeois, 2011). On the other hand, positive correlations with previous October temperature are stronger with decreasing dominance. Intermediate trees thus seem to profit more from translocation than co-/dominant trees. Possibly, this phenomenon is related to a higher dependence of smaller trees on previous year reserves, as these trees are more resource-limited due to smaller crowns and rooting zones. Besides differences in competition for resources between trees of different sizes, micro-climatic variations in the canopy may be suggested as an influencing factor ( $c f$. Aussenac, 2000; Orwig \& Abrams, 1997). No clear explanation could be found for the absence of a positive correlation with previous October temperatures at the NW and SW aspects.

Positive associations with temperature in January are indicated for all chronologies in our RDA, and are particularly strong at SW (Fig. 3.4). This positive growth response might be explained by decreasing winter embolism with increasing winter temperatures, although small vessels in beech are not very sensitive to winter embolism (Lemoine et al., 1999). A warm winter may further influence bud-burst phenology and prolong growing seasons (Lebourgeois et al., 2005).

In conclusion, for our study sites in the Swabian Alb we found that beech trees belonging to co-/dominant social classes are particularly sensitive to dry conditions from June to August at the NW and SW aspects. Differences in drought sensitivity between dominance classes might relate to higher evaporative water losses of co-/dominant trees, as transpiration of individual trees is proportional to leaf area and irradiation intensity (cf. Střelcová et al., 2002). Differences between aspects likely relate to lower irradiation at NE and lower AWC levels at SW. In a future warmer climate with more frequent and severe summer droughts (cf. Christensen et al., 2007) growth and competitiveness of beech may be negatively affected in this area.

Acknowledgments The author is grateful to Stadtwald Tuttlingen for supporting the tree sampling. He would like to thank two anonymous reviewers who significantly helped on improving earlier versions of this manuscript. Also Felix Baab and Clemens Koch are thankfully acknowledged for their field assistance and technical support in the lab. This study was conducted with financial support of the EU-FP7 project MOTIVE (Models for adaptive forest management, grant No. 226544).

\section{References}

Ammer, C., Albrecht, L., Borchert, H., Brosinger, F., Dittmar, C., Elling, W., Ewald, J., Felbermeier, B., Von Gilsa, H., Huss, J., Kenk, G., Kölling, C., Kohnle, U., Meyer, P., Mosandl, R., Moosmayer, H.U., Palmer, S., Reif, A., Rehfuess, K.E., \& Stimm, B. 2005. Zur Zukunft der Buche (Fagus sylvatica L.) in Mitteleuropa: kritische Anmerkungen zu einem Beitrag von Rennenberg et al. (2004). Allgemeine Forst- und Jagd Zeitung, 176, 60-67. Cited on page 1.

Aranda, I., Gil, L., \& Pardos, J.A. 2000. Water relations and gas exchange in Fagus sylvatica L. and Quercus petraea (Mattuschka) Liebl. in a mixed stand at their southern limit of distribution in Europe. Trees - Structure and Function, 14, 344-352. Cited on page 9.

Aussenac, G. 2000. Interactions between forest stands and microclimate: ecophysiological aspects and consequences for silviculture. Annals of Forest Science, 57, 287-301. Cited on page 10.

Barbaroux, C., \& Bréda, N. 2002. Contrasting distribution and seasonal dynamics of carbohydrate reserves in stem wood of adult ring-porous sessile oak and diffuse-porous beech trees. Tree Physiology, 22, 1201-1210. Cited on page 9 .

Becker, M., Landmann, G., \& Lévy, G. 1989. Silver fir decline in the Vosges Mountains (France): role of climate and silviculture. Water Air and Soil Pollution, 48, 77-86. Cited on page 8.

Becker, M., Nieminen, T.M., \& Gérémima, F. 1994. Short-term variations and long-term changes in oak productivity in northeastern France. The role of climate and atmospheric $\mathrm{CO}_{2}$. Annals of Forest Science, 51, 477-492. Cited on page 8 .

Biondi, F., \& Waikul, K. 2004. DENDROCLIM2002: A C++ program for statistical calibration of climate signals in tree-ring chronologies. Computers and Geosciences, 30, 303-311. Cited on page 4. 
Bontemps, J-D., Hervé, J-C., \& Dhôte, J-F. 2009. Long-term changes in forest productivity: a consistent assessment in even-aged stands. Forest Science, 55, 549-564. Cited on page 1.

Bontemps, J-D., Hervé, J-C., \& Dhôte, J-F. 2010. Dominant radial and height growth reveal comparable historical variations for common beech in north-eastern France. Forest Ecology and Management, 258, 1455-1463. Cited on page 1.

Bouriaud, O., Bréda, N., Moguédec, G., \& Nepveu, G. 2004. Modelling variability of wood density in beech as affected by ring age, radial growth and climate. Trees - Structure and Function, 18, 264-276. Cited on pages 4 and 9.

Cescatti, A., \& Piutti, E. 1998. Silvicultural alternatives, competition regime and sensitivity to climate in a European beech forest. Forest Ecology and Management, 102, 213-223. Cited on page 9.

Charru, M., Seynave, I., Morneau, F., \& Bontemps, J-D. 2010. Recent changes in forest productivity: an analysis of national forest inventory data for common beech (Fagus sylvatica L.) in north-eastern France. Forest Ecology and Management, 260, 864-874. Cited on page 1.

Cherubini, P., Dobbertin, M., \& Innes, J.L. 1998. Potential sampling bias in long-term forest growth trends reconstructed from tree rings: a case study from the Italian Alps. Forest Ecology and Management, 109, 103-118. Cited on page 9.

Christensen, J.H., Hewitson, B., Busuoic, A., Chen, A., Gao, X., Held, R., Jones, R., Kolli, R.K., Kwon, W-T., Laprise, R., Magana Rueda, V., Mearns, L., Menéndez, C.G., Räisänen, J., Rinke, A., Sarr, A., \& Whetton, P. 2007. Regional climate projections. Pages 847-940 of: Solomon, S., Qin, D., Manning, M., Chen, Z., Marquis, M., Averyt, K.B., Tignor, M., \& Miller, H.L. (eds), Climate Change 2007: The physical science basis. Contribution of Working Group I to the fourth assessment report of the Intergovernmental Panel on Climate Change. Cambridge: Cambridge University Press. Cited on pages 1 and 10.

Ciais, P., Reichstein, M., Viovy, N., Granier, A., Ogée, J., Allard, V., Aubinet, M., Buchmann, N., Bernhofer, C., Carrara, A., Chevallier, F., de Noblet, N., Friend, A.D., Friedlingstein, P., Grünwald, T., Heinesch, B., Keronen, P., Knohl, A., Krinner, G., Loustau, D., Manca, G., Matteucci, G., Miglietta, F., Ourcival, J.M., Papale, D., Pilegaard, K., Rambal, S., Seufert, G., Soussana, J F., Sanz, M.J., Schulze, E.D., Vesala, T., \& Valentini, R. 2005. Europewide reduction in primary productivity caused by the heat and drought in 2003. Nature, 437, 529-533. Cited on page 1 .

Cook, E.R. 1985. A time-series analysis approach to tree-ring standardisation. Ph.D. thesis, The University of Arizona, Tucson, Arizona. Cited on page 3.

Cook, E.R., \& Peters, K. 1981. The smoothing spline: a new approach to standardizing forest interior tree-ring width series for dendroclimatic studies. Tree-Ring Bulletin, 41, 45-53. Cited on page 3.

de Luis, M., Novak, K., Čufar, K., \& Raventós, J. 2009. Size mediated climate-growth relationships in Pinus halepensis and Pinus pinea. Trees - Structure and Function, 23, 1065-1073. Cited on page 9.

Dittmar, C., \& Elling, W. 1999. Radial growth of Norway spruce and European beech in relation to weather and altitude. Forstwissenschaftliches Centralblatt, 118, 251-270. Cited on pages 1, 8, and 9.

Dittmar, C., Zech, W., \& Elling, W. 2003. Growth variations of common beech (Fagus sylvatica L.) under different climatic and environmental conditions in Europe - a dendroecological study. Forest Ecology and Management, 173, 63-78. Cited on pages 1,8 , and 9.

Drobyshev, I., Övergaard, R., Saygin, I., Niklasson, M., Hickler, T., Karlsson, M., \& Sykes, M.T. 2010. Masting behavior and dendrochronology of European beech (Fagus sylvatica L.) in southern Sweden. Forest Ecology and Management, 259, 2160-2171. Cited on page 9.

Epron, D., \& Dreyer, E. 1990. Stomatal and non stomatal limitation of photosynthesis by leaf water deficits in three oak species: a comparison of gas exchange and chlorophyll a fluorescence data. Annals of Forest Science, 47, 435-450. Cited on page 9. 
Friedrichs, D.A., Trouet, V., Büntgen, U., Frank, D.C., Esper, J., Neuwirth, B., \& Löffler, J. 2009. Species-specific climate sensitivity of tree growth in central-west Germany. Trees - Structure and Function, 23, 729-739. Cited on pages 1,4 , and 9 .

Fritts, H.C. 1976. Tree rings and climate. London: Academic Press. Cited on pages 2, 3, and 8.

García-Suárez, A.M., Butler, C.J., \& Baillie, M.G.L. 2009. Climate signal in tree-ring chronologies in a temperate climate: a multi-species approach. Dendrochronologia, 27, 183-198. Cited on page 9.

Geßler, A., Schrempp, S., Matzarakis, A., Mayer, H., Rennenberg, H., \& Adams, M.A. 2001. Radiation modifies the effect of water availability on the carbon isotope composition of beech (Fagus sylvatica). New Phytologist, 150, 653-664. Cited on page 3.

Geßler, A., Keitel, C., Kreuzwieser, J., Matyssek, R., Seiler, W., \& Rennenberg, H. 2007. Potential risks for European beech (Fagus sylvatica L.) in a changing climate. Trees - Structure and Function, 21, 1-11. Cited on page 1.

Gómez-Aparicio, L., García-Valdés, R., Ruíz-Benito, P., \& Zavala, M.A. 2011. Disentangling the relative importance of climate, size and competition on tree growth in Iberian forests: implications for forest management under global change. Global Change Biology, 17, 2400-2414. Cited on page 9.

GreenLeaf-website. 2011. Website GreenLeaf Project. http://greenleaf.unl.edu/downloads/ [Accessed on: 18.3.2011]. Cited on page 3.

Grundmann, B.M., Bonn, S., \& Roloff, A. 2008. Cross-dating of highly sensitive common beech (Fagus sylvatica L.) tree-ring series with numerous missing rings. Dendrochronologia, 26, 109-113. Cited on page 8.

Hauser, S. 2003. Dynamik hochaufgelöster radialer Schaftveränderungen und des Dickenwachstums bei Buchen (Fagus sylvatica L.) der Schwäbischen Alb unter dem Einfluss von Witterung und Bewirtschaftung. Ph.D. thesis, Albert-Ludwigs-University Freiburg, Germany. Cited on page 2.

Hildebrand, E., Augustin, S., \& Schack-Kirchner, H. 1998. Bodenkundliche Charakterisierung der Kernflächen. Pages 7-12 of: Rennenberg, H. (ed), Buchendominierte Laubwälder unter dem Einfluß von Klima und Bewirtschaftung: Ökologische, waldbauliche und sozialwissenschaftliche Analysen - Vorcharakterisierung der Untersuchungsfächen. Freiburg: Eigenverlag der Universität Freiburg. Cited on pages 2 and 3.

Holst, T., Rost, J., \& Mayer, H. 2005. Net radiation balance for two forested slopes on opposite sides of a valley. International Journal of Biometeorology, 49, 275-284. Cited on page 2.

Jump, A.S., Hunt, J.M., \& Peñuelas, J. 2006. Rapid climate change-related growth decline at the southern range edge of Fagus sylvatica. Global Change Biology, 12, 2163-2174. Cited on page 1.

Kahle, H. 2006. Impact of the drought in 2003 on intra- and inter-annual radial growth of beech and spruce along an altitudinal gradient in the Black Forest, Germany. Pages 151-163 of: Heinrich, I., Gärtner, H., \& Schlesser, G. (eds), TRACE - Tree Rings in Archaeology, Climatology and Ecology - Proceedings of the DENDROSYMPOSIUM 2005, vol. 4. Schriften des Forschungszentrums Jülich-Reihe Umwelt. Cited on page 1.

Kölling, C., Walentowski, H., \& Borchert, H. 2005. Die Buche in Mitteleuropa: eine Waldbaumart mit grandioser Vergangenheit und sicherer Zukunft. AFZ-Der Wald, 60, 696-701. Cited on page 1.

Kozlowski, T.T., \& Pallardy, S.G. 1997. Growth control in woody plants. San Diego: Academic Press. Cited on pages 5 and 9.

Kraft, G. 1884. Zur Lehre von den Durchforstungen, Schlagstellungen und Lichtungshieben. Hannover: Klindworth. Cited on page 3.

Lachaud, S., \& Bonnemain, J-L. 1981. Xylogenèse chez les Dicotylédones arborescentes. I. Modalités de la remise en activité du cambium et de la xylogenèse chez les Hêtres et les Chênes Ãćgés. Canadian Journal of Botany, 59, 1222-1230. Cited on page 4.

Lebourgeois, F. 2007. Climatic signal in annual growth variation of silver fir (Abies alba Mill.) and spruce (Picea abies Karst.) from the French Permanent Plot Network (RENECOFOR). Annals of Forest Science, 64, 333-343. Cited on page 8 . 
Lebourgeois, F., Bréda, N., Ulrich, E., \& Granier, A. 2005. Climate-tree-growth relationships of European beech (Fagus sylvatica L.) in the French Permanent Plot Network (RENECOFOR). Trees - Structure and Function, 19, 385-401. Cited on pages 8, 9, and 10.

Legendre, P., \& Legendre, L. 1998. Numerical ecology. Developments in environmental modelling. Amsterdam: Elsevier. Cited on page 4.

Lemoine, D., Granier, A., \& Cochard, H. 1999. Mechanism of freeze-induced embolism in Fagus sylvatica L. Trees - Structure and Function, 13, 206-210. Cited on page 10.

Lepš, J., \& Šmilauer, P. 2003. Multivariate analysis of ecological data using CANOCO. Cambridge: Cambridge University Press. Cited on page 4.

Matzarakis, A., Mayer, H., Schindler, D., \& Fritsch, J. 2000. Simulation des Wasserhaushalts eines Buchenwaldes mit dem forstlichen Wasserhaushaltsmodell WBS3. Tech. rept. Meteorological Institute, Albert-Ludwigs-University Freiburg, Germany. Cited on page 3.

Mayer, H., Holst, T., \& Schindler, D. 2002. Microclimate within beech stands - part I: photosynthetically active radiation. Forstwissenschaftliches Centralblatt, 121, 301-321. Cited on page 2.

Mérian, P., \& Lebourgeois, F. 2011. Size-mediated climate-growth relationships in temperate forests: a multi-species analysis. Forest Ecology and Management, 261, 1382-1391. Cited on pages 9 and 10.

Mund, M., Kutsch, W.L., Wirth, C., Kahl, T., Knohl, A., Skomarkova, M.V., \& Schulze, E.D. 2010. The influence of climate and fructification on the inter-annual variability of stem growth and net primary productivity in an oldgrowth, mixed beech forest. Tree Physiology, 30, 689-704. Cited on page 9.

Neuwirth, B., Schweingruber, F.H., \& Winiger, M. 2007. Spatial patterns of Central European pointer years from 1901 to 1971. Dendrochronologia, 24, 79-89. Cited on pages 8 and 9.

Orwig, D.A., \& Abrams, M.D. 1997. Variation in radial growth responses to drought among species, site, and canopy strata. Trees - Structure and Function, 11, 474-484. Cited on page 10.

Paar, U., Guckland, A., Dammann, I., Albrecht, M., \& Eichhorn, J. 2011. Häufigkeit und Intensität der Fruktifikation der Buche. AFZ-Der Wald, 26-29. Cited on page 9.

Palmer, W.C. 1965. Meteorological drought. Office of Climatology, US Weather Bureau, Washington DC, Weather bureau paper, vol 45. Cited on page 3.

Peñuelas, J., \& Boada, M. 2003. A global change-induced biome shift in the Montseny mountains (NE Spain). Global Change Biology, 9, 131-140. Cited on page 1.

Peñuelas, J., Ogaya, R., Boada, M., \& Jump, A.S. 2007. Migration, invasion and decline: changes in recruitment and forest structure in a warming-linked shift of European beech forest in Catalonia (NE Spain). Ecography, 30, 829-837. Cited on page 1.

Piovesan, G., \& Adams, J.M. 2001. Masting behaviour in beech: linking reproduction and climatic variation. Canadian Journal of Botany, 79, 1039-1047. Cited on page 9.

Piovesan, G., Biondi, F., Di Filippo, A., Alessandrini, A., \& Maugeri, M. 2008. Drought-driven growth reduction in old beech (Fagus sylvatica L.) forests of the central Apennines, Italy. Global Change Biology, 14, 1265-1281. Cited on page 1 .

Piutti, E, \& Cescatti, A. 1997. A quantitative analysis of the interactions between climatic response and intraspecific competition in European beech. Canadian Journal of Forest Research, 27, 277-284. Cited on page 2.

Raftoyannis, Y., \& Radoglou, K. 2002. Physiological responses of beech and sessile oak in a natural mixed stand during a dry summer. Annals of Botany, 89, 723-730. Cited on page 9.

Rennenberg, H., Seiler, W., Matyssek, R., Geßler, A., \& Kreuzwieser, J. 2004. Die Buche (Fagus sylvatica L.) - ein Waldbaum ohne Zukunft im südlichen Mitteleuropa? Allgemeine Forst- und Jagd Zeitung, 175, 210-224. Cited on page 1. 
Rolland, C., Desplanque, C., Michalet, R., \& Schweingruber, F.H. 2000. Extreme tree rings in spruce (Picea abies [L.] Karst.) and fir (Abies alba Mill.) stands in relation to climate, site, and space in the southern French and Italian Alps. Arctic Antarctic and Alpine Research, 32, 1-13. Cited on page 6.

Saurer, M., Borella, S., Schweingruber, F., \& Siegwolf, R. 1997. Stable carbon isotopes in tree rings of beech: climatic versus site-related influences. Trees - Structure and Function, 11, 291-297. Cited on page 9.

Scharnweber, T., Manthey, M., Criegee, C., Bauwe, A., Schröder, C., \& Wilmking, M. 2011. Drought matters declining precipitation influences growth of Fagus sylvatica L. and Quercus robur L. in north-eastern Germany. Forest Ecology and Management, 262, 947-961. Cited on pages 2, 8, and 9.

Schmitt, U., Möller, R., \& Eckstein, D. 2000. Seasonal wood formation dynamics of beech (Fagus sylvatica L.) and black locust (Robinia pseudoacacia L.) as determined by the "pinning" technique. Journal of Applied Botany, 74, 10-16. Cited on page 9.

Schweingruber, F.H. 1996. Tree rings and environment dendroecology. Bern: Haupt Verlag. Cited on page 8.

Skomarkova, M., Vaganov, E., Mund, M., Knohl, A., Linke, P., Boerner, A., \& Schulze, E.D. 2006. Inter-annual and seasonal variability of radial growth, wood density and carbon isotope ratios in tree rings of beech (Fagus sylvatica) growing in Germany and Italy. Trees - Structure and Function, 20, 571-586. Cited on page 9.

Spiecker, H., Kahle, H., \& Hauser, S. 2001. Klima und Witterung als Einflußfaktoren für das Baumwachstum in Laubwäldern: retrospektiven Analysen und Monitoring. Pages 307-333 of: Rennenberg, H. (ed), Buchendominierte Laubwälder unter dem Einfluß von Klima und Bewirtschaftung: Ökologische, waldbauliche und sozialwissenschaftliche Analysen - Vorcharakterisierung der Untersuchungsflächen; Abschlußbericht des SFB 443. Freiburg: Eigenverlag der Universität Freiburg. Cited on page 3.

Střelcová, K., Matejka, F., \& Mindáš, J. 2002. Estimation of beech tree transpiration in relation to their social status in forest stand. Journal of Forest Science (Prague), 48, 130-140. Cited on page 10.

Tardif, J., Camarero, J.J., Ribas, M., \& Gutiérrez, E. 2003. Spatiotemporal variability in tree growth in the central Pyrenees: climatic and site influences. Ecological Monographs, 73, 241-257. Cited on page 4.

ter Braak, C.J.F. 1994. Canonical community ordination. Part I: basic theory and linear methods. Ecoscience, 1, 127-140. Cited on page 4.

ter Braak, C.J.F., \& Šmilauer, P. 2002. CANOCO reference manual and CanoDraw for Windows user's guide: software for canonical community ordination (version 4.5). Ithaca (NY): Microcomputer Power. Cited on page 4.

van der Schrier, G., Briffa, K.R., Jones, P.D., \& Osborn, T.J. 2006. Summer moisture variability across Europe. Journal of Climate, 19, 2818-2834. Cited on page 3.

van der Werf, G.W., Sass-Klaassen, U.G.W., \& Mohren, G.M.J. 2007. The impact of the 2003 summer drought on the intra-annual growth pattern of beech (Fagus sylvatica L.) and oak (Quercus robur L.) on a dry site in the Netherlands. Dendrochronologia, 25, 103-112. Cited on pages 1 and 9.

Ward, J.H. 1963. Hierarchical grouping to optimize an objective function. Journal of the American Statistical Association, 58, 236-244. Cited on page 4.

WebWerdis. 2011. German Weather Serivce (DWD): Web-based Weather Request and Distribution System. http://www.dwd.de/webwerdis [Accessed on: 15.3.2011]. Cited on page 3.

Wells, N., Goddard, S., \& Hayes, M.J. 2004. A self-calibrating Palmer drought severity index. Journal of Climate, 17, 2335-2351. Cited on page 3.

Wigley, T.M.L., Briffa, K.R., \& Jones, P.D. 1984. On the average value of correlated time series, with applications in dendroclimatology and hydrometeorology. Journal of Climate and Applied Meteorology, 23, 201-213. Cited on pages 3 and 4 . 